\title{
Where Have All The Young Girls Gone?
}

Fatal Discrimination of Daughters-A Regional Comparison

\section{Marina Thorborg}

\section{OpenEdition}

\section{Journals}

Édition électronique

URL : http://journals.openedition.org/chinaperspectives/1120

DOI : 10.4000/chinaperspectives. 1120

ISSN : 1996-4617

Éditeur

Centre d'étude français sur la Chine contemporaine

Édition imprimée

Date de publication : 15 février 2005

ISSN : 2070-3449

\section{Référence électronique}

Marina Thorborg, "Where Have All The Young Girls Gone? », China Perspectives [En ligne], 57 | january february 2005, mis en ligne le 21 juin 2007, consulté le 28 octobre 2019. URL : http://

journals.openedition.org/chinaperspectives/1120 ; DOI : 10.4000/chinaperspectives.1120

Ce document a été généré automatiquement le 28 octobre 2019

(c) All rights reserved 


\title{
Where Have All The Young Girls Gone?
}

\author{
Fatal Discrimination of Daughters-A Regional Comparison
}

\section{Marina Thorborg}

1 Hong Kong in 1972. A picture in the South China Morning Post shows a crying mother surrounded by all her daughters. Her only son has disappeared, maybe kidnapped. A caption under the photograph cites what the weeping woman is saying: "I would give all my daughters away if only I can get my son back". This type of situation and similar reactions were frequently reported in this and other papers in Hong Kong during 1972-1973.

2 My first reaction was, how are the daughters reacting to this? Were they not hurt knowing they were worth only a fraction of another child? According to the newspaper reports the young girls just sat there during the interview and display signs of being upset only for the loss of a sibling. Was the old Chinese saying, "better to have a crippled son than eight healthy daughters" still valid for their mother, family, and kin? And in that case why?

3 Apparently this is still the case today as new data reveal how would-be daughters in not only China but also in other Chinese societies and in South Asia are aborted in their millions as foetuses because of their sex. Already in 1990 it was estimated by the later Economy Nobel prize laureate Amartya Sen that one hundred million women were "missing" in the world, most of them concentrated to South Asia and China". So many young girls have already been eliminated that it is showing in the demographics of the youth in these populations ${ }^{2}$. International and Chinese media have devoted a number of reports to the plight of the "surplus" of fifty million young men who cannot find a wife, while mainly women's organisations have asked the crucial question, "Why has fatal discrimination of daughters returned to China?"3.

4 How much a society values its women and particularly its young females is revealed more by demographic data, than by self-congratulatory speeches on Women's Day or any number of enlightened laws promulgated but never really implemented ${ }^{4}$. If half the 
population, the female half, is decimated, or left markedly behind, this clearly shows the real value society accords to women ${ }^{5}$.

If a society continues to build its welfare system and particularly its old age care on the conception of the special responsibility of a son, this might be directly inviting discrimination against daughters and according them a lesser value. Hence how old-age support is organised might be more a crucial factor for the survival of female foetuses, young daughters and women, than rigidly enforced birth planning per se. This is what this article will look into, by comparing China with other societies in the region that do not have forced family planning and some of them more affluent.

Demographic data do not only reveal sex discrimination in the immediate past but also show the cumulative impact of prolonged differential treatment according to gender. New research is showing that there is no one straightforward connection between economic modernisation per se and higher value accorded to women or any other disadvantaged group for that matter ${ }^{6}$.

7 Another assumption was that rapid development and economic growth contribute somehow automatically more to gender equality than a slower tempo. But recent research has proved it to be rather the other way around ${ }^{7}$.

Demographic sources

8 National differences in definitions, concepts, procedures in data collection and estimation methods limit the comparability of demographic data for international comparisons; but they can be used for indicating trends. In developing countries lack of communications further adds to the difficulties: the ease with which data can be obtained also influence their quality ${ }^{8}$, especially when relating to such huge countries as China and India'. The level of trust towards authorities in a society also contributes to the quality of the information obtained ${ }^{10}$.

9 There always exists a multitude of reasons for concealing data from authorities such as avoiding taxes, military service, restrictions on births, or prolongation of benefits ${ }^{11}$.

Infant and child mortality rates in a comparative setting

10 Infant mortality refers to the age group of zero to one year old and child mortality to the age group of one to five years. Some composite, demographic data usually carry more national prestige than others, such as infant mortality rates, as this has usually been hailed as a sign of how far a country has developed with regard to social progress. How fast a country manages to decrease the mortality of its most vulnerable group, the infants, informs us as well how it treats and values their mothers ${ }^{12}$. After 1960, Taiwan, Hong Kong and Singapore closely follow Japan in the rapid reduction of its infant mortality in line with a general economic upsurge (see Table 1). 
1. Trends in infant mortality (0-1 years old)

\begin{tabular}{|c|c|c|c|c|c|c|c|c|c|c|}
\hline & 1920 & 1930 & 1909 & 1997 & 1960 & 1970 & 1960 & 1990 & 2000 & 2000 \\
\hline India & 195 & 181 & 156 & $151 / 127$ & 87 & $137 \pi 20$ & 120705 & $94 / 72$ & $60 / 2$ & 6366 \\
\hline Sri Lanka & 102 & 175 & 166 & $101 \times 2$ & 57 & seto & $44 / 34$ & 2649 & $17 / 13$ & $17 / 16$ \\
\hline Caina & $>200$ & $300 / 200$ & $>200$ & 204 & 330710 & 8552 & 40041 & $61 / 30$ & 3728 & $35 \sqrt{30}$ \\
\hline Tulwan & . & 154 & 1451140 & 35 & 31 & 16 & 10 & GS & 6. & 6 \\
\hline Japan & 166 & $125 / 118$ & 1584107 & $77 \approx 2$ & 30 & $14 / 13$ & 87 & 5.4 & 4 & 3 \\
\hline South Kares & : & $97 / 60$ & $104 / 73$ & 71 & 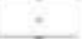 & 46043 & 3076 & $238:$ & 25 & QS \\
\hline Hoey Kotg & : & : & 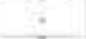 & 108 & 48 & 1918 & 11 & 6 & 3 & 3 \\
\hline Singapore & : & 2141777 & 131 & 8781 & 35 & 2020 & 128 & 84 & 43 & $3 / 2$ \\
\hline Philippines & 57 & $165 / 138$ & $149 / 137$ & 11297 & 8572 & 67.60 & $65 / 43$ & 6324 & 3199 & $28 x$ \\
\hline Burms & . & 202 & 204 & 136 & 158 & 128122 & 10944 & 9447 & 80449 & $90 \mathrm{n}$ \\
\hline
\end{tabular}

11 In China after 1949 peace contributed to decreased mortality rates. However, a famine in 1954 and the devastating Great Leap famine in 1959-1961-claiming from 43 to 60 million lives-created peaks of infant mortality at pre-war levels ${ }^{13}$. However, the positive trends, which began in the 1950s resumed with increased welfare in the mid-1960s whereby China made rapid advances in decreasing infant mortality (see Table 1$)^{14}$.

Through a multitude of different campaigns China made vigorous attempts to change the attitude towards women during the Maoist era, 1949-1976 ${ }^{15}$. Started half-heartedly in the mid-1950s and mainly touching urban areas, China's birth control campaign resurfaced in the early 1960s then halted during the Cultural Revolution and was renewed in the 1970s. The two-child family ideal of the 1970s was in 1980 turned into the one-child family promoted through a vigorous campaign. This coincided with the de facto de-collectivisation of the countryside with the withering away of the rudimentary social safety net set up during the People's Communes from 1958 onwards, and a return to family agriculture. Hence the male line of the immediate family was again left as the ultimate security for its members as it had been for the more than two millennia of this patriarchal, patrilocal and patrilinial culture.

Simultaneously with sons becoming even more valuable-both as workers in renewed family agriculture and as future old-age support for peasants-new techniques of prenatal screening enabling sex selective abortions was introduced, contributing both to hiding of births and abortion of female foetuses.

14 A substantial number of births since 1980 have occurred unreported. One report mentioned a 33\% undercount in Sichuan in 1981, and another 5\% unreported in Jingan county, Shanghai ${ }^{16}$. Underreporting has been one way of avoiding forced abortions. Chinese sources cite the amount of unreported births as one-third of all deliveries by 1990 and the number of unreported deaths to $12 \%$ of all deaths ${ }^{17}$. While the State Statistics Bureau, for example, stated the number of births in China in 1998 to be 19.91 million, the State Family Planning Agency reported 13.83 million! ${ }^{18}$

15 One survey reported that in Canton over three-quarters of all maternal deaths in the year 2000 involved women from the "floating population", though this migrant population made up less than one-third of the total population. An official inquiry showed that more than half of these deaths were caused by insufficient medical care ${ }^{19}$. A report concluded, "with some evidence pointing to increased maternal mortality among migrant populations as a result of lack of access to proper health care" ${ }^{20}$. As many of these deceased 
would-be mothers were trying to give birth secretly neither birth nor death of these infants would have been registered.

From 1953 until 1970, in regard to infant mortality according to sex, China followed a general Asian and also global trend of showing a higher male infant mortality, as

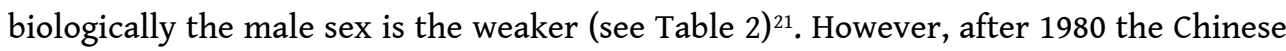
female infant mortality has been the higher. South Korea as well showed excess female infant mortality in the $1980 \mathrm{~s}^{22}$. There is a significant marked discrimination against daughters in South and East Asia, though not in South-East Asia, with Burma as an example of this, nor the rest of the world ${ }^{23}$. A subsequent lower child mortality (age group of 1-5 years) rate can therefore be a function of a high infant mortality rate (age group of 0-1 years), meaning those meant to die, either by nature or human interference were already dead, which could explain that China was in 1997-2002 the only country with a claimed child mortality rate below the age of ten where more girls than boys were dying (see table 3). However, foreign demographers judge this to be an under-evaluation ${ }^{24}$. This situation stands in contrast to South-East Asia with the Philippines as an example of this (See Table 2) ${ }^{25}$. In South Asia, Sri Lanka became early on an exception with a rapid reduction of infant mortality while the rest of South Asia continued on a high level well into this millennium (see Table 1).

\section{Infant mortality by sex}

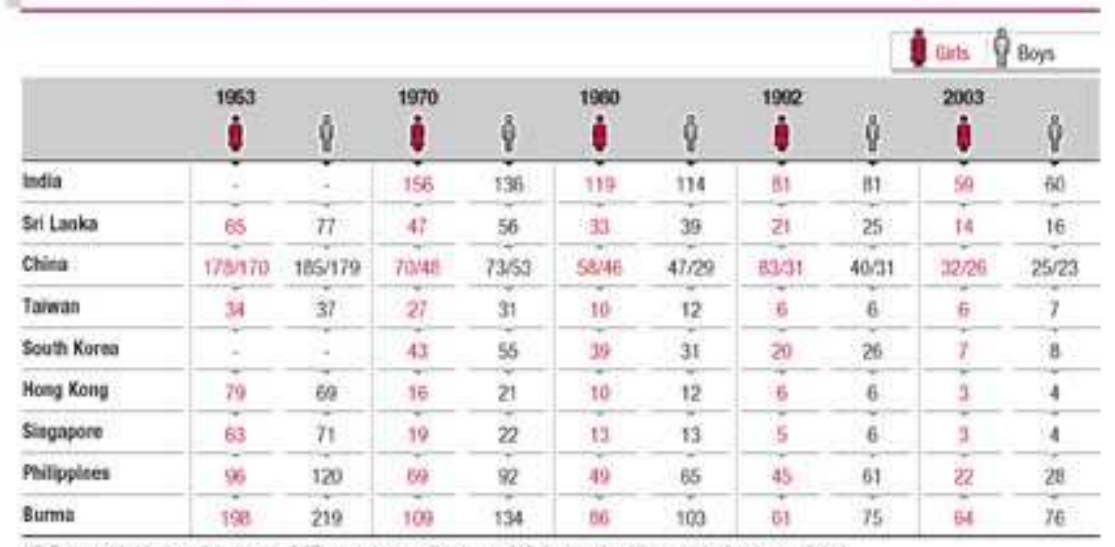

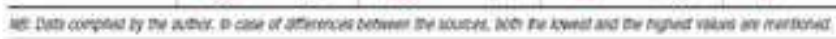

\section{Child mortality ( 1 to 5 years old) by sex}
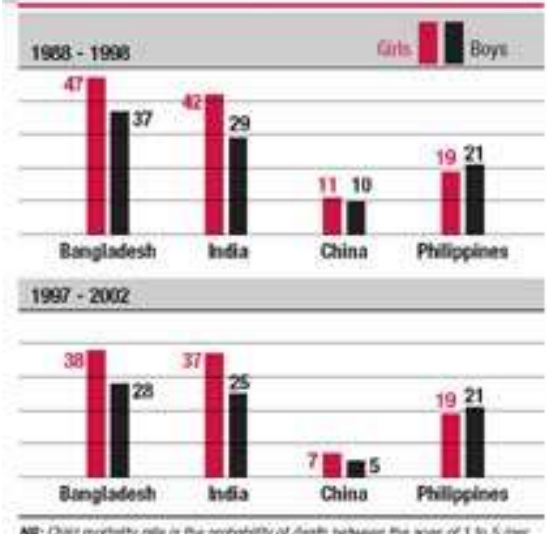

$$
\text { Not: Des: }
$$

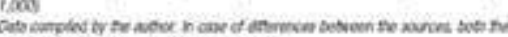

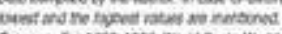

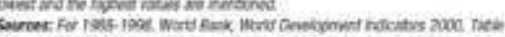

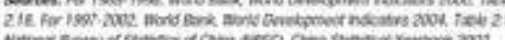

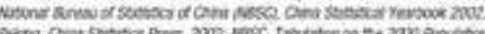

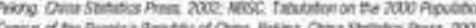


Sex ratios among the youngest, 0-4 years old

How many men to 100 women there are on average in a population determines what is called the sex ratio. This ratio is a function not only of the sex ratio at birth but also of population growth, migration patterns by sex, life expectancy, and the general level of mortality (and an assumed "gender"-neutrality in the trends of mortality). The biological norm is about 105 boys born for every 100 girls and from there on the sex ratio evens out. When comparing sex ratios globally those most distorted today are overwhelmingly concentrated in $\mathrm{Asia}^{26}$.

Daughter discrimination is normally considered a practice of the poor. But with modern technology in the form of prenatal screening this has increasingly become an urban middle-class phenomenon ${ }^{27}$. Hence there could be no racial exceptions to this norm, as sometimes suggested by the Chinese ${ }^{28}$. From 1953 until 1980, China's traditionally high sex ratio lowered somewhat, coinciding with a rudimentary social safety net being set up in rural areas ${ }^{29}$. When China reverted to a type of tenancy agriculture in the early 1980s, the safety net set up under the collective system disintegrated and the sex ratios of children aged 0-4 years, rapidly became more unbalanced (See Figure 4) ${ }^{30}$.

\section{Sex ratios by age ( $0-4$ years oid $)$}

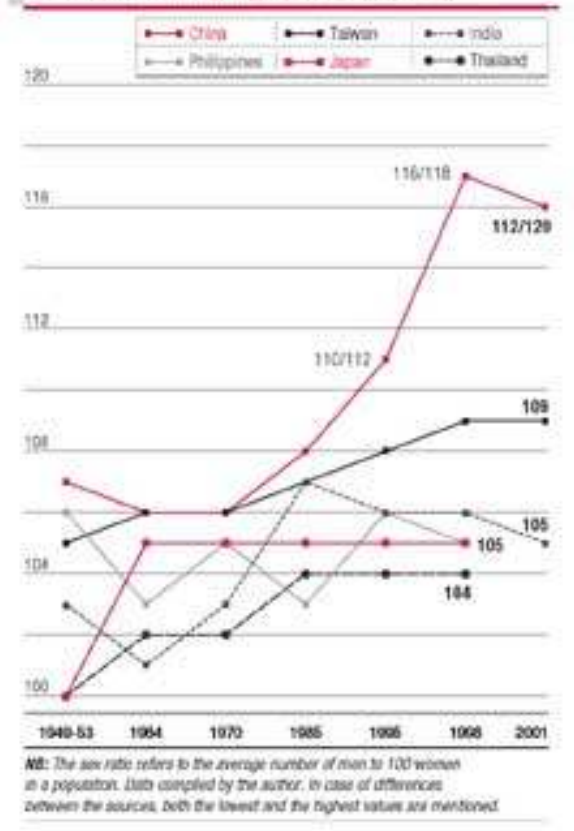

Whatever misgivings people might have harboured about abortions as such were most likely crushed by the severity of the application of the one-child-family policy with forced abortions even as late as into the third trimester of pregnancy. Hence to abort a foetus of the "wrong" sex could in such an environment be seen as a necessary adjustment to the prevailing policy. If the state through its local representatives tampered with and forced the abortion of foetuses it would be hard to convince people that they could not do the same according to their own preferences. The state had in this case already lost the moral high ground in the eyes of the people, no matter what official policy said, what counted was how this policy was implemented locally ${ }^{31}$.

According to most Chinese official data, the sex ratio among the youngest age cohort 0-4 years was 106 boys in China in the late 1950s until the late 1970s, and had risen to 120 in 2001 (see Figure 4), and was over 121 by $2003^{32}$. However, in 2000 the sex ratio 
was only 105 in the 15 to 19 age cohort, born between 1981 and 1985. If the sex ratio of that cohort when it was $0-4$ years old in the early 1980 s was 108 and later 105, that would indicate that a number of girls had appeared from nowhere (meaning they had never been registered) or, that so many had boys died thereby altering the sex ratio. The latter scenario is not very likely given that the overall mortality rate by sex was higher for girls. This would indicate how much caution must be employed when using these estimates.

Today China has the widest gap in the sex ratio among its youngest citizens in the world (see Figure 4) ${ }^{33}$, with some unforeseen consequences. In 1982, a survey revealed that less than $1 \%$ of the women but $9 \%$ of the men aged 30-34 had never married. This first age cohort of new China (born 1948-1952) reflected partly the lack of women in old China $^{34}$.

This serious situation is being recreated today as up to one-quarter of all young men cannot find a wife, and is currently being called "a disaster more frightening than war" 35 .

West China's-Tibet, Xinjiang and Yunnan-have the most natural sex ratios while the most industrialised parts along the southeast coast, except Zhejiang province, show skewed sex ratios. The most unfavourable are found in central south China (See Map 5). The more Han Chinese the area is, the less girls are allowed to live. The one-child policy, which began in 1980 was at first not enforced for national minorities, then eventually very cautiously, which might be part of the explanation. Another explanation might be that couples of mixed marriages between a Han and a minority who would earlier have chosen to register as Han, as this carried more benefits, were registering less often as this allowed them to have more children when the one-child policy was implemented ${ }^{36}$.

\section{Sex ratios at birth in China in 1999}

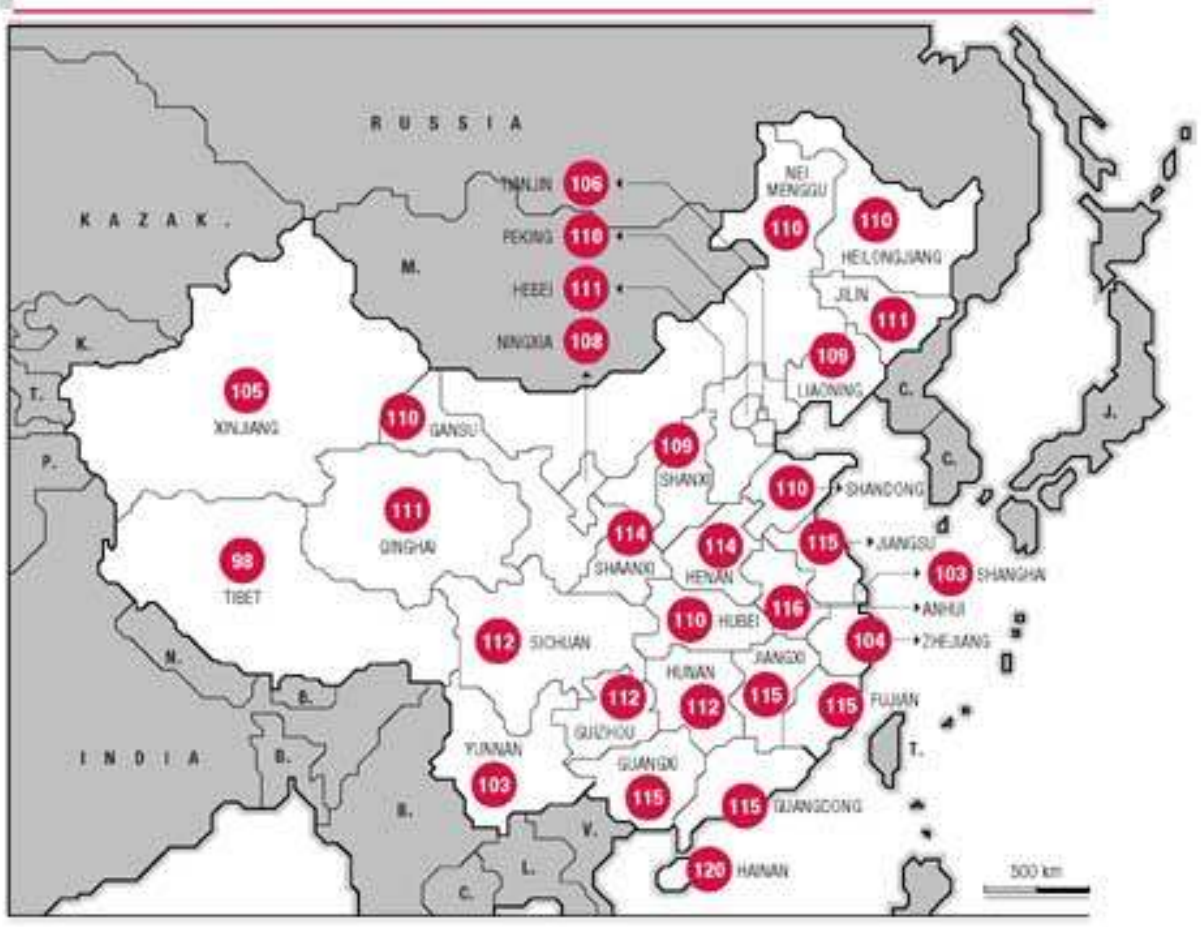

Although regional variations are great in China they are even more so in India (see Map 6). The regional figures for India clearly demonstrate a severe lack of girls in the 
northwest provinces, while the rest of India-and particularly the eastern and southern areas-show more balanced sex ratios ${ }^{37}$. In 1981, Kerala's ratio was 97, while it was 114 in Punjab and 115 in Haryana, the two latter states being more affluent ${ }^{38}$. Here again wealth was no deterrent to heavier discrimination against females ${ }^{39}$.

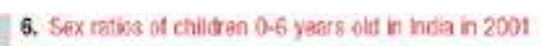

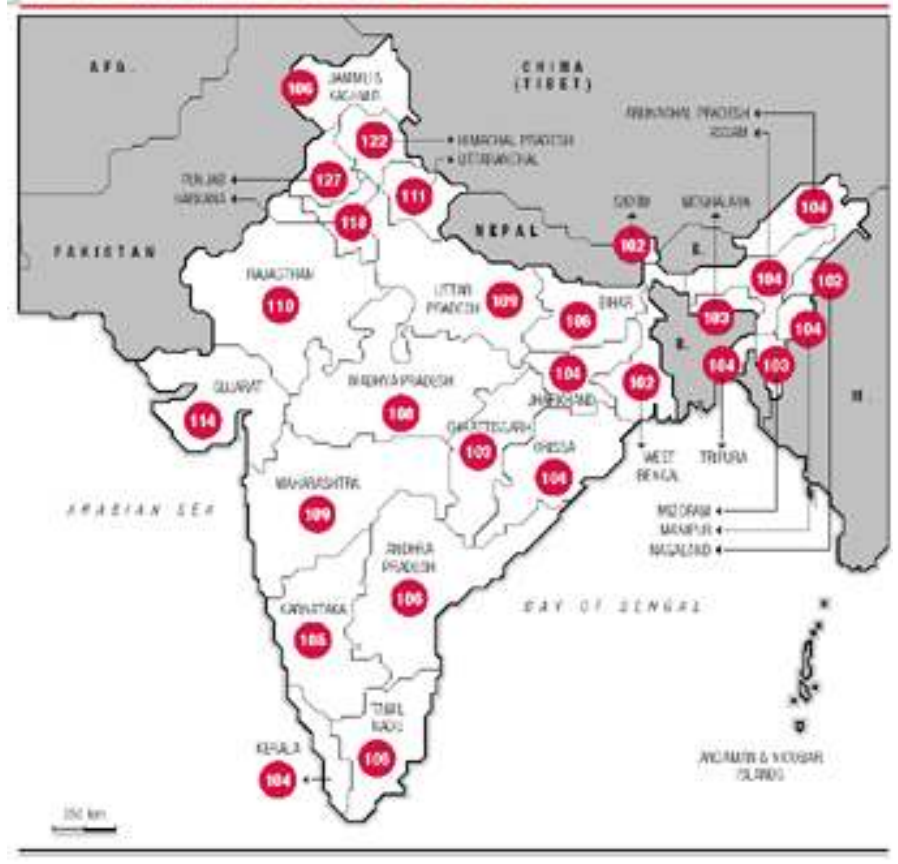

Missing young women

All through recorded history, infants have been killed by their parents in emergency situations. Europe, for example, has a long history of baby killing, institutionalised well into the nineteenth century by "angel makers" ${ }^{40}$. In China, emperors and later modern leaders have tried to outlaw infanticide ${ }^{41}$. Worldwide well over 100 million women are currently missing, mainly in South Asia and China through neglect, infanticide or abortion ${ }^{42}$. One reason for this blaring sex discrepancy would be the low value accorded to daughters expressed in the selective abortions-more widely available from the 1970s.

All through Chinese and also Japanese recorded history, poor people used the age-old method of selecting after the baby was born, which meant killing or abandoning a baby girl ${ }^{43}$. From the 1980 s on, more and more of the upper and middle classes, particularly in China and in India, have resorted to selective abortion. Though forbidden by law, this is widely practised showing up in distorted sex ratios at birth ${ }^{44}$. This means that poverty as such would not be the driving factor, as used to be the standard explanation for the traditional drowning of baby girls in imperial China. The rigid one-child policy in China could be used as an explanation, but it applied only to urban areas. In rural areas the one-child policy-later modified-has been complied with by about $1 \%$ of the population and sex proportions are more distorted in rural areas than in urban ones ${ }^{45}$.

With the withering away of the state sector and its "Iron Rice Bowl"-the cradle-tograve safety net for workers-insecurity in old age has returned to urban China. Having a son might be increasingly preferred for support in old age, although different kinds of new, old-age reforms are under trial implementation ${ }^{46}$. 
Son-preference as a remnant of a traditionally patrilineal society could be an explanation for this, but in a whole generation, with collective agriculture and a rudimentary social safety net from the 1950 s to the 1980 s, this was not such a visible phenomenon-the lowest sex ratios were recorded in the mid-1960s ${ }^{47}$. The lack of a social security net-particularly for old age-in rural areas could be closer to an understanding of son-preference as daughters still marry out, while married sons are considered responsible for their parents in old age, a finding that can be gathered from local surveys ${ }^{48}$. Hence at times rigid population policy by the government including forced abortions combined with a favouring of the urban areas in social policy could be part of an explanation, implying that when birth rates go or are forced down daughter discrimination increases ${ }^{49}$. This could mean that discriminatory social policy against the rural population as such could be one main cause for the increasingly disproportionate sex ratio in rural China.

Citing a report from 2002 "Current government policies... generate migration through extreme neglect of rural areas" 50 ; and “.... China's development policies which involve the deliberate and systematic underdevelopment of rural areas" 51 . Considering these constraints then, the fatal discrimination of daughters for the individual rural family might seem a rational solution in a situation where at least $90 \%$ of the rural population have no pensions for old age ${ }^{52}$. As recent surveys of the elderly in China has shown that even if son support is available most able-bodied old people in rural areas work- $80 \%$ of the men and half of the women in the formal sector until age 69 , including $38 \%$ of the seriously ill. All the elderly who were childless worked. The more and the closer parents lived with a son the less they worked and the better was their living standard. Most old people surveyed worked as long as they could in order to delay their dependence on a son until they really could no longer manage ${ }^{53}$.

As regards the current situation "the central authorities have balked at consolidating pensions into a national framework because the central government is not yet prepared financially to guarantee the old-age incomes of urban workers, not to mention those of rural inhabitants" 54 . Even in the richest areas of China such as Canton, pension coverage is too narrow and too small. Hence for the foreseeable future for the majority of the population no real alternatives exist to almost "work till you drop" and relying on your son ${ }^{55}$.

31 Calculating the missing young women according to a global standard-by comparing societies with similar life expectancy and infant mortality rates-shows that urbanised and affluent Taiwan, South Korea and Singapore display similar patterns of discrimination though none has implemented anything other than mild and voluntary family planning campaigns (see Table 7). In these societies as well, a general social security net for old age has not been a priority, although a beginning might be in the making in Taiwan ${ }^{56}$. In Singapore the notion of filial piety was revived when a new law was promulgated in 1995 on care for elderly parents. Heated debate ensued when it was revealed that mainly elderly people dominated among the poor in Singapore in 2000 while the rest of society was getting wealthier. Even in rich and advanced Japan the new premier Koizumi when taking office in 2001 acknowledge rapid ageing of the population as one major problem facing society.

In China, the vital role of sons for old age security can be regarded as one main cause of fatal discrimination against daughters. In India, researchers usually attribute the increased materialism of the middle class-expressed in excessive dowry outlays and 
demands-to the killing of women, either as foetuses or as young brides (see Table 2). These gross imbalances between the sexes do not show among the poorest groups in India, where for necessity a woman's economic contribution and therefore her value is higher in the family ${ }^{57}$.

In South-East Asia with markedly less of a social security system for old age, but with a bilateral kinship system-meaning parents on both sides are just as important-all the different variables showing sex discrimination are of a different order and closer to the trends of the rest of the world ${ }^{58}$.

Hence mainly economic forces, but through the prism of culture-sons as support in old age-contribute to the killing of the female foetus, infant, child and young bride in both poor and affluent East and South Asia.

Western Europe needed more than a century to develop old age security while population ageing was slow. In Sweden, for example, it took 85 years for those aged 65+ to grow from $7 \%$ to $14 \%$ of the population, while in Japan it was 25 years. In China it is projected to be 30 years, for South Korea 20 years and only 18 for Singapore ${ }^{59}$. Hence the problems here are of a different magnitude. The demographic consequences of the one-child policy will more likely lead to more elderly working in rural as well as urban China in the future. If the notions of filial piety are weakening and not supplanted by equivalent daughter support the foreseeable future indeed looks bleak for the elderly. Will this lead to diminished daughter discrimination? Having a daughter born after the early 1980s means that most likely, if she wants to, she can marry and have a child. Having a son born at the same time could mean that even if he wants to, he might be among that quarter of the young male surplus population that cannot find anyone to marry, joining an army of predictably more than 50 million bachelors.

\section{7. "Missing" young women in 2001}

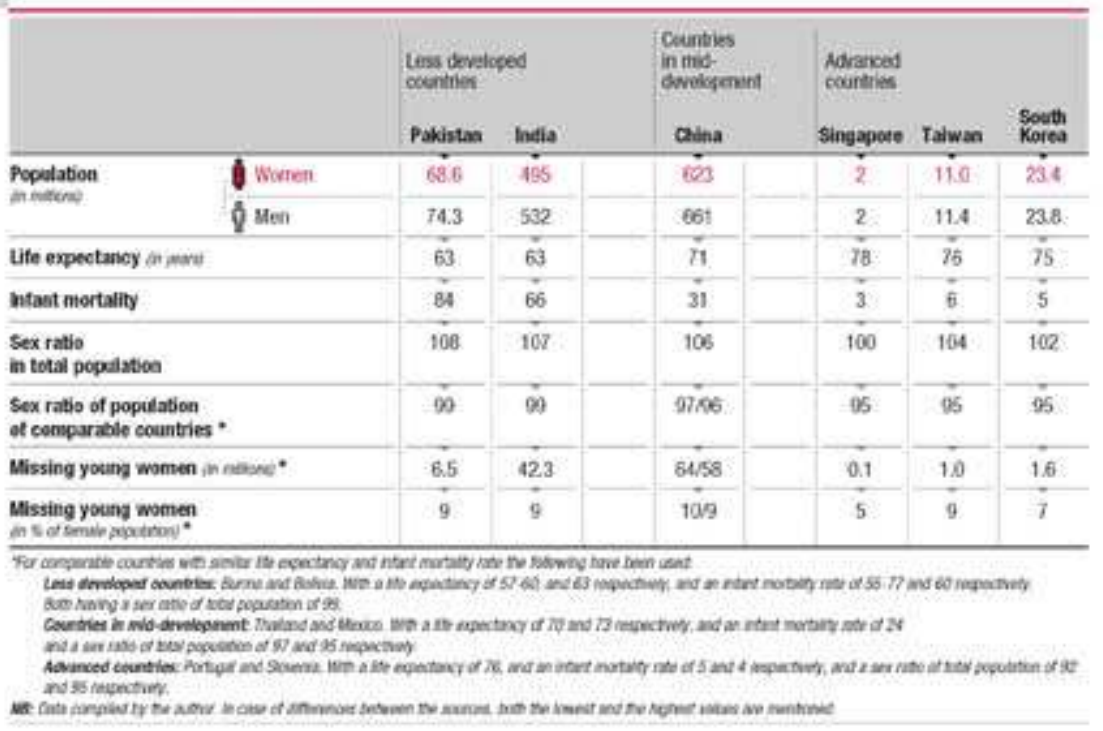

Affluence and rapid economic growth have not been changing the demographic imbalance between the sexes in East Asia, while lack of this was earlier used as a standard explanation for South Asia. In South and East Asia, women continue to fare worse than men. South-East Asia, however, shows a much more favourable demographic set-up for women. 


\section{NOTES}

See United Nations Demographic Yearbook (UNDY), 1948, Table 26 for Singapore and for Hong Kong pre-1949 refer to 1948 in UNDY, 1949/50 Table 27. For South Korea see UN, The World's Women Trends and Statistics, New York, 2000, Chart 3.3.

\section{NOTES DE FIN}

1. Amartya Sen, "More Than 100 Million Women Are Missing", The New York Review, December 20th 1990.

2. Elisabeth Croll, Endangered Daughters Discrimination and Development in Asia, London, Routledge, 2000.

3. Gilles Pison, "Moins de naissances mais un garcon à tout prix : 1'avortement sélectif des filles en Asie" (Less births but a boy at any price: selective abortion of girls in Asia) in Population et Sociétés, Paris, No. 404, September 2004, and Annika Danielsson, 
“Mansöverskott besvärlig följd av Kinas befolkningspolitik" (Male surplus disturbing result of Chinese population policy) TT, April 23rd 2004. See also TT-Reuters, "Kina försöker få stopp på aborter av flickfoster" (China tries to stop abortions of female foetuses), Peking, August 12th 2004, and Martin King Whyte, cited in Valerie M. Hudson and Andrea M. den Boer, Bare Branches Security Implications of Asia Surplus Male Population, MIT Press, Cambridge, Mass., London, 2004, p. 27, and Wang Qiangzhuang, “China's Population: Imbalance of Gender Proportions", FBIS-CHI-98-042, February 11th 1998.

4. Amartya Sen, Development as Freedom, London, Oxford University Press, 1999.

5. Lawrence Haddad, “Women's Status: Levels, Determinants, Consequences for Malnutrition, Interventions, and Policy", in Asian Development Review, Vol. 17, No. 1, 1999.

6. Marina Thorborg, "Research on Women in the Chinese Economy" in Theoretical and Methological Problems in Research on Women in developing Countries, No. 5/82, Women's Research Centre in Social Sciences, Copenhagen, 1982, and Marina Thorborg, Identification of Priority Research Issues on Women in Asia and the Pacific - A Report on Research and Research Organizations with Bibliography, SAREC Documentation, Stockholm, 1985 (1st edition), 1986 (2nd edition). See also Marina Thorborg, Chinese Women, An Annotated Bibliography, Swedish International Development Authority, Stockholm, 1995. 7. Stephanie Seguino, "Gender, quality of life, and growth in Asia 1970-90", in The Pacific Review, Vol. 15, No. 2, 2002.

8. Thorborg, 1982, op. cit.

9. Marina Thorborg, "Befolkningspolitik i Kina från Confucius till våra dagar" (Population Policy in China from Confucius to today ), in Den Ny Verlden, Centre for Development Research, Copenhagen, 1987/ 4.

10. Marina Thorborg, "Confidence, Corruption and Culture - The Role of Media in Developing Civil Society", in Ioan Horga \& Renaud de Brosse (eds.), The Role of MassMedia and of the New Information and Communication Technologies in the Democratisation Process of Central and Eastern European Countries, International Institute of Administrative Studies, Bruxelles, 2002.

11. Marina Thorborg, "Comment on "China: End of Population Dynamics"' in PRC Tomorrow: Development under the Ninth Five-Year Plan, National Sun Yat-Sen University, Taiwan, 1996.

12. In regard to the countryside there exists a reinterpretation of the J. L. Buck survey from 1929-31, but both the original and its later re-construction are open to dispute. However Princeton demographers arrived at a rural infant mortality rate of some $30 \%$. See Judith Banister, China's Changing Population, Stanford, Stanford University Press, 1987, pp. 3-7.

13. Dali L. Yang, Calamity and Reform in China State, Rural Society, and Institutional Change Since the Great Leap Famine, Stanford University Press, 1996, and Jasper Becker, Hungry Ghosts China's Secret Famine, London, An Owl Book, 1996. See also Kenneth Hill, Demographic Trends in China from 1950 to 1982, World Bank Discussion Papers 22, The World Bank, Washington D.C., 1988.

14. Marina Thorborg, "Women under Maoism The Struggle to End Discrimination Against and to Introduce Welfare for Women Workers", in Cheng Ying et al. (eds.), Frauenstudien, Munchen, K.G. Saur Verlag, 1992.

15. Ibid. See also Marina Thorborg, "Chinese Employment Policy in 1949-78 With Special Emphasis on Women in Rural. Production", in Chinese Economy Post-Mao, Joint 
Economy Committee, Congress of the United States, November 1978, US Government Printing Office, Washington D.C., 1978.

16. Mary E. Young, André Prost, Child Health in China, World Bank Staff Working Papers, No. 767, Washington D. C., 1985, pp. $5 \mathrm{ff}$.

17. Thomas Scharping, Birth Control in China 1949-2000 Population policy and demographic development, London, RoutledgeCurzon, 2003, Chap. 10-12.

18. US Department of State, China, 2000, from http://www.state.gov/g/drl/rls/hrrpt/ 2000/eap/684.htm, March 21st 2003.

19. Human Rights in China, HRIC, "Institutionalized Exclusion: The tenuous legal status of internal migrants in China's major cities, A report by Human Rights in China", November 6th 2002.

20. "Institutionalized Exclusion", China Rights Forum, No. 1, 2003.

21. While more female infants than male ones died in North China in the 1930s, the reverse was true in south China. See Banister, 1987, Chap. 4, op. cit.

22. During the pre-war period in times of stress both Singapore and Hong Kong recorded an excess of female infant mortality. In Singapore under the latter part of the Japanese occupation during the Second World War there was a higher female than male infant mortality rate. In 1944 and 1945 the female infant mortality rate was 295 and 222 , respectively, compared to a male rate of 284 and 210, but after the occupation in 1946 it again reverted to a higher male infant mortality rate. Hong Kong too experienced higher female mortality rates in 1948 and 1953, but neither city did later revert to a higher female rate. (See Figure 1) Hence for Singapore in times of crises and insecurity the traditional son-preference-whereby sons are a guarantee for care and support in old age what also can be called fatal daughter discrimination-set in. The same explanation would go for Hong Kong in the 1940s and the 1950s with a large refugee population.

\section{RÉSUMÉS}

This article looks at regional discrimination against daughters in China. To see where and why this discrimination occurs, it considers a number of demographic variables, such as infant and child mortality by sex as well as sex ratios of populations in East, South-East, and South Asia. It refutes the idea that rigid population control is the main cause of skewed sex ratios. An amalgam of cultural and economic factors are seen as the main contributing causes including a lack of institutionalised old age support from the state and a culture that gives the main responsibility for this to sons. 